\title{
Management of Maritime Tourism of the Kei Indigenous Peoples of Southeast Maluku Regency as an Economic Driver Based on Environmental Sustainability
}

\author{
Rory Jeff Akyuwen, Hendrik Salmon, Barzah Latupono, Muchtar Anshary Hamid Labetubun, La Ode Angga*
}

Faculty of Law, Pattimura University, Ambon 97233, Indonesia

Corresponding Author Email: rory@jakyuwen

https://doi.org/10.18280/ijsdp.160820

Received: 21 September 2021

Accepted: 11 December 2021

\section{Keywords:}

marine tourism management, Kei indigenous peoples, environmental sustainability economy

\begin{abstract}
The development of marine tourism in the Kei community of Southeast Maluku Regency has a very important role both in terms of economic law and environmental law. In terms of economic law, the development of marine tourism plays a role in increasing the country's foreign exchange income and improving the economy of the Kei people of Southeast Maluku Regency. This research was conducted using an empirical juridical approach which is a descriptive qualitative analysis research. This study tries to describe what happens in the management of marine tourism in the Kei Indigenous community as an environmentally friendly economic driver based on environmental sustainability. The answers found from this research are: 1 . Factors that affect environmental damage caused by: a. anthropogenic (human activities), b. non-anthropogenic (ecological changes, natural factors), c. Awareness of people living around marine tourism areas in Southeast Maluku Regency. 2. The factors that influence the level of community income in marine tourism locations are business capital variables that have a strong or significant effect on people's income in Kei Indigenous Maritime Tourism, Southeast Maluku Regency. In addition to the factors above, there are also several influencing factors, namely: 1) The Effect of Business Length on Community Income on Marine Tourism 2) The Effect of Education Level, 3 The Effect of the Number of Visitors.
\end{abstract}

\section{INTRODUCTION}

The Indonesian environment has a total coastline of 80,000 kilometers and a sea area of 3.1 million square kilometers. Even though it has a vast sea, not all of them can be used as potential for marine tourism. shallow relief so that it is safe for water tourism activities, such as snorkeling, canoeing, and boating by boat.

Marine tourism is all activities that are recreational activities whose activities are carried out on marine or marine media and include coastal areas, surrounding islands, and ocean areas in terms of their surface; in it, or basically including in the arrival of the garden of links [1]. The development of marine tourism has a very important role both economically and ecologically. Economically, the development of marine tourism plays a role in increasing the country's foreign exchange income and improving the economy of the community around the area. In particular, the benefits of tourism are as follows: Increase opportunities for business for residents or communities living around tourist attractions. The tourism sector can absorb labor which can increase the income and welfare of the population.

Maritime tourism is part of the marine economy, which is an economic activity carried out in coastal and oceanic areas as well as on land that uses natural resources and marine environmental services to produce goods and services. The purpose of tourism development is not only to increase foreign exchange earnings for the country, but it will be expected and expected to act as a development catalyst (agent of development).
The Kei archipelago, which the locals call Nuhu Evav (Evav Islands) or Tanat Evav (Evav Country), is an administrative part of the Maluku Province. The islands are located to the south of the Bird's Head peninsula, Irian Jaya (Papua), to the west of the Aru Islands, and to the northeast of the Tanimbar Islands. The Kei Islands consist of several islands, including Kei Besar (Nuhu Yuut or Nusteen), Kei Kecil (Nuhu Roa or Nusyanat), Tanimbar Kei (Tnebar Evav), Kei Dulah (Du), Dulah Laut (Du Roa), Kuur, Taam, and Tayandu (Tahayad). In addition, there are still a number of small uninhabited islands. The total land area of the Kei Islands is $1438 \mathrm{~km}^{2}$ (555 sq mi) [2].

The Southeast Maluku Tourism Promotion Board said the islands have a number of tourist attractions. "The Kei Islands have 112 islands with 76 tourist destinations. It is famous for its fine sandy beaches and the culture that exists there. The Kei Islands have beautiful beaches such as Ngurbloat, Ngurtavur, Ngur Sarnadan, and Bair Island. "Ngurbloat Beach is recognized by National Geographic as the beach with the softest sand in the world. This beach, which in the local language is called Ngurbloat, is located in Ngilngof Village. This beach has a coastline of 3 kilometers. The fine sand like flour is one of the attractions of this beach. In addition, tourists can dive because 400 meters from the shore there are ravines and expanses of coral reefs. This beach is always crowded on weekends, and has a pavilion that tourists can use. To enter here, tourists are charged Rp. 20,000 per car and Rp. 5.000 per motorbike.

Satisfied playing on the beach, try to go to Hawang Cave and enjoy the sensation of swimming in the cool and clear air 
of the cave. This cave is Mul Hawang which in the local language means ghost or demon. At first, this cave was often used for meditation. Pond in Hawang Cave, Langgur, Southeast Maluku This cave is one of the tourist attractions in Southeast Maluku, becoming a tourist destination for local residents and tourists.

Besides that, there is the Masbait Prayer Hill. This hill is a prayer hill and religious tourism area in Southeast Maluku, Kei Islands. This hill, which has a height of about 300 meters above sea level, is the highest point in Kei Kecil. Masbait Prayer Hill can be reached by car, followed by walking for about 30 minutes. This hill is a prayer hill and religious tourism area in Southeast Maluku. For Catholics and Christians, this hill is often the location of the Way of the Cross procession during Easter celebrations. At the top of the hill, tourists can see the statue of Jesus Blessing which was a gift from Pope John Paul then there is also Baer Island. is one of the locations that must be visited when traveling to the Kei Islands. Located in the north of Kei, with a distance of 1 hour. Tourists can depart from the fishing port of Dullah which is close to Tual Harbor or from Watdek Harbor in Langgur, Southeast Maluku. Baer Island has a calm lagoon, tourists can swim as well as snorkel. If you have the guts, tourists can also see from the 20 meter high cliff on the island. There is also Adranan Island, in the Kei Islands group, Adranan Island is one of the islands that can be used as a stop for tourists to enjoy lunch after being satisfied playing on Baer Island. Located only 30 minutes from Baer Island, Adranan Island offers white sand and blue sea as a view while enjoying lunch.

Adranan Island, in the Kei Islands group the tourism sector causes the economy of the surrounding community to increase. The arrival of tourists to a tour also raises the emergence of foreign businessmen or encourages someone to become an entrepreneur. Providing services and facilities for tourists while traveling in the Kei Islands has a strategy in national development because it is the center of national activities for the capture fisheries sector. This is evidenced by the determination of the Kei Islands to become one of the minapolitan areas in Indonesia in accordance with the Decree of the Minister of Maritime Affairs and Fisheries numbered KEP.32/MEN/2010. Administratively, the Kei Islands consist of one district and one city, namely Southeast Maluku District and Tual City. Meanwhile, the waters of the Kei Islands are included in WPP 714 (Banda Sea) which have great potential for fishing.

In managing tourism, one of the goals is to move the economic cycle of the Kei Indigenous people who are around the location of the tourism activities. The management and management must comply with applicable legal rules such as polluting and destroying the environment as regulated in Article 87 of Law Number 32 of 2009 concerning Environmental Protection and Management (UUPPLH-2009). Article 87 paragraph (1) UUPPLH-2009 states [3]:

"Every person in charge of a business and/or activity who commits a violation in the form of a violation of the law and/or environmental destruction that causes harm to other people or the environment is obligated to pay compensation and/or take certain actions".

In addition to violating UUPPLH it also contradicts the provisions of Article 1365 of the Civil Code (KUHPerdata) which states:

"Every act that violates the law and brings harm to others, obliges the person who caused the loss because of his mistake to cause the loss."
From these legal problems, the formulation of the problems that will be studied in this paper are: 1 . What factors influence the non-compliance of tourism managers with UUPPLH-2009 in the Kei Customary Law community? 2. The influence of the level of community economic income with the existence of marine tourism in Southeast Maluku Regency?

\section{LITERATURE REVIEW}

The theoretical framework used in this paper are: 1. Theory of the Legal Welfare State, 2. Theory of Legal Effectiveness.

\subsection{Welfare state theory}

In this paper, the author uses the Welfare State Law Theory approach as a Grand Theory, supported by the Applied Theory Legal Effectiveness Theory. The use of state theory as a Grand Theory with the argument and understanding of the state that, in the concept of environmental law development in the Management of Marine Tourism in the Kei Indigenous Peoples as an Economic Driver Based on Environmental Sustainability, is an embodiment that is based on the function of the state to create welfare (welfare state) in dealing with and overcome problems in the field of protection and management of natural resources and the environment.

The theory of the State of Law on Child Welfare in this paper is used to analyze the extent to which the involvement of the State in this case is the Government, Provincial, Regency and City Governments in the protection and management of natural resources and the environment in Indonesia so as to give birth to the people, the State or the Government, the Regency and City Provincial Governments. , is considered unable to release it to improve the welfare of the community in relation to the protection and management of natural resources and the environment in Indonesia. That the state or government needs to intervene in the management of natural resources and the environment, including the regional spatial plan so that the resources of the people's prosperity are not controlled by a few people [4].

In the theory of the welfare state law, reflecting that for the public interest or the government in the implementation of the public interest has become very broad, the possibility of supporting the interests of the people by the state apparatus is also very broad. In carrying out these tasks, the state administration requires independence, namely the independence to be able to act on its own initiative, especially in solving critical problems that arise where regulations do not yet exist. Due to the wide range of government functions in the context of a modern law state or welfare state, of course the wider role of administrative law is in it.

The rule of law is a state that places legal power as its power and the exercise of that power in all forms is carried out under the rule of law. Based on this view, all administrators of power in a country are based on law. The law becomes an instrument for controlling state life.

According to John Locke, state power based on law is divided into legislative, executive and federative powers, besides that the state must contain 4 (four) elements, namely as follows [5]:

a. The state aims to guarantee the human rights of citizens.

b. State administrators are based on law. 
c. There is a separation of state powers in the public interest.

d. The supremacy of the legislature that supports the interests of the people.

John Locke's view above influenced Montesquieu, the function of the state must be separated into three powers of state power, namely executive, executive and judicial. The positions of these three powers are balanced, one cannot be higher than the other.

In the theory of the welfare state, the goal of the state is seen as an instrument to achieve common goals, namely prosperity and social justice for all Indonesian people [6]. The theory of the welfare state is a combination of the concepts of the state and the welfare state. According to Kansil et al. [6], "State of law (Rechtsstaat) is a state that places the law as the basis of its power and exercises that power in all forms carried out under the rule of law".

Meanwhile, the concept of the welfare state according to Bagir Manan is:

"The state or government does not only maintain security or the main community, but bears the responsibility to realize justice, general welfare for the prosperity of the people" [7].

The birth of the welfare state as a reaction to the failure of the classical legal state concept and the socialist state law state. The two concepts and types of rule of law have different basis and form of state control over economic resources. Theoretically, these differences are motivated and influenced by the ideology or ideas they hold. The classical liberal law state is influenced by the notion of liberalism or the classical legal state, while the socialist legal state is influenced by Marxism [8].

The theory of the state is based on efforts to maintain freedom within the state while justifying the intervention of the authorities in the administration of the people's welfare and general welfare. The Indonesian welfare state that is followed is included in the Preamble to the 1945 Constitution of the Republic of Indonesia and in several articles including Article 33 paragraph (3) of the 1945 Constitution of the Republic of Indonesia. Article 33 paragraph (3) of the 1945 Constitution of the Republic of Indonesia does not only contain provisions on state rights regarding earth, water and natural resources contained in the 1945 Constitution of the Republic of Indonesia. in it, but also contains a provision that the control of the state is used for the greatest prosperity of the people. These two aspects of the rule cannot be separated from each other, both are a systematic unity [9]. In the sense that the state positions and places itself as a regulator, regulates, regulates, carries out management actions, and carries out supervision to ensure that its people enjoy the management of natural resources in the environment and spatial planning for the welfare and prosperity of the people. The function of the state is how to provide service functions to the community in order to create general welfare.

The Indonesian people who have natural resources and the environment have the power to regulate and manage and make the best use of these natural resources for the prosperity of the people [10]. Then for further implementation, considering that it is impossible for the state to implement it alone, the right of control as the day-to-day implementation of government, through the institutions it establishes, can cooperate with entrepreneurs (investors). Which in its implementation must pay attention to the principles of prudence, efficiency, transparency, environment and social justice for all Indonesian people [11].
Thus, state ownership of natural resources in which the management of marine tourism in the Aday Kei community must give birth to social justice and general welfare for all Kei people and the environment. In order to fulfill this, every policy issued by the government relating to the protection and management of natural resources and the environment is implemented. In connection with the theory of the welfare state, W. Friedman in setting up an economic system that favors the people cannot be separated from the function of the state that adheres to the state theory, which can carry out 4 (four) functions, namely [12]:

a. The State as Provider (the state as a servant) of the people's welfare;

b. State as Regulator (state as regulator);

c. State as Entrepreneur (state as entrepreneur);

d. State as Referee (state as referee).

In these four functions of the state in the economic field, the most essential function lies in the regulatory function. If the regulator function is wrong or neglects to place it, it will have an impact on the other three functions. Therefore, in carrying out the function of government regulators, it must pay attention to moral norms and applicable legal norms.

Regarding the theory of the welfare state, Utrecht said as follows [13]:

"The government of a modern legal state keeps security in its broadest sense, namely social security in the community. In a welfare state, the era of the liberal economy has ended and the liberal economy has been replaced by an economy that is more led by the center (central geleid economie).

The task of the government is no longer only as a night watchman (nachtwakerstaat) and cannot be passively silent, but must actively participate in community activities so that for all people can be more guaranteed [14].

Kelsen mentions this as follows:

"In all modern legal systems, states as well as other legal entities, can have personal rights, any rights and obligations determined by private law. When there is civil law, the norms apply to individuals and the state" [15].

Free translation:

"In all modern legal systems, as is the case with other individuals, the state can have rights in persona, over all matters and obligations regulated by civil law. If there are civil provisions, then the norms are treated equally both to individuals and to the state".

Based on the spirit contained in Article 33 of the 1954 UUDNRI [16], both the government and the people must jointly strive to realize the welfare of the community. National development activities based on the principles of togetherness and kinship in accordance with the 1945 Constitution of the Republic of Indonesia have a very broad meaning where the community cannot leave efforts to achieve prosperity solely in the hands of the government. The achievement of goals must be carried out hand in hand between the welfare of the community and the government.

\subsection{Legal effectiveness theory}

In this paper, the author will also conduct an assessment of the problem by using the theory of legal effectiveness as an Applied Theory proposed by Soerjono Soekanto. The word "effective" comes from the English language, namely effective, which means something that is carried out successfully. The word "effective" can also be interpreted as something that has an effect (influence, effect) since the commencement of a law 
or regulation, according to the Big Indonesian Dictionary [9].

While the effectiveness itself is a state in which he is played to unite [17]. From a legal point of view, what is meant by "he" here is a party who is not a police officer. The word effective itself is born from the word effective, which means that there is an effect or result that occurs in an action. According to Soerjono Soekanto, one of the functions of law, both as a rule and as an attitude or behavior, is to consider human behavior, the problem of legal influence is not only limited to compliance or compliance with the law, but includes the total effect of legal action on actions or behaviors that are good is either positive or negative. The effectiveness of law enforcement is closely related to the effectiveness of the law. In order for the law to be effective, it is necessary for law enforcement officers to enforce these sanctions. A sanction can be actualized to the community in the form of strength (compliance), with these conditions indicating an indicator that the law is effective.

According to Soerjono Soekanto, the factors that influence the effectiveness of the law are as follows [18]

\subsubsection{Legal factor}

Law contains uncertainty, certainty and expediency. In practice, it is not uncommon for law and justice to occur. Legal certainty is concrete, someone is tangible, justice is abstract so that when deciding a case only by applying the law, there are times when the value of justice is not achieved. So, when looking at a problem regarding the law at least it becomes a top priority. Because law is not only seen from the point of written law, but also takes into account other factors that develop in society. Meanwhile, from the other side, justice is created because justice contains subjective elements from each person.

\subsubsection{Law enforcement factor}

Law enforcement is related to the parties that form and apply the law. The parts of law enforcement are law enforcement officers who are able to provide certainty, justice and proportional benefit of the law. Law enforcement officials include the notion of law enforcement institutions and law enforcement officers, while law enforcement officers in a narrow sense start from the police, prosecutors, judiciary, legal advisors and correctional institution officers. Each apparatus and apparatus is given the authority to carry out each of them which includes the activities of receiving reports, investigating, investigating, praising, proving, imposing verdicts and imposing sanctions, as well as efforts to retrain the convicts. There are three important elements that affect the working mechanism of law enforcement officers and officers, including:

a) Law enforcement institutions along with various supporting facilities and infrastructure and institutional working mechanisms;

b) Work culture related to the apparatus, including regarding the welfare of the apparatus;

c) The set of regulations that support both institutional performance and regulate legal materials that are used as work standards, both material law and procedural law.

Systematic law enforcement efforts must pay attention to these three aspects simultaneously, so that the process of law enforcement and internal justice can be realized in real terms.

\subsubsection{Factors of legal facilities or facilities}

Supporting facilities can simply be formulated as a means to achieve goals. The scope is mainly physical facilities that function as supporting factors. These facilities include skilled and skilled human resources, good organization, adequate equipment, adequate finance, and so on.

In addition to the availability of facilities, maintenance is also very important for sustainability. It often happens that regulations are already functioning, facilities are not fully available. This condition will only lead to counter-productivity which should speed up the process instead causing congestion to occur.

\subsubsection{Community factor}

Law enforcement aims to achieve achievements in society. People have certain opinions about the law. That is, the effectiveness of the law is also on the willingness and legal awareness of the community. Low awareness of the community will make it difficult for law enforcement, while the steps that can be taken are socialization by involving social layers, power holders and law enforcers themselves. The formulation of the law must also relate to social changes with the law which in the end the law can be effective as a means of regulating people's behavior.

\subsubsection{Cultural factor}

Cultural factors that are actually unified with community factors are deliberately distinguished. Because in the discussion the problem of the value system that is at the core of spiritual or non-material culture is raised. This is because as a system (or a subsystem of the social system), the law includes the structure, substance of the social system, then the law includes structure, substance, and culture. The structure includes the container or form of the system, for example, includes the arrangement of formal legal institutions, the law between these institutions, rights and obligations, and so on.

\section{METHODOLOGY}

This research was conducted using an empirical juridical approach which is a descriptive qualitative analysis research [19]. This study seeks to describe what happens in the management of marine tourism in the Kei Indigenous people of Southeast Maluku Regency as an environmental-based economic driver. The location of this research was carried out at marine tourism sites managed by the Kei Indigenous people.

\section{RESULTS AND DISCUSSION}

\subsection{Location and geographical condition of the research area}

4.1.1 Astronomy position

Astronomically, Southeast Maluku Regency is located at a coordinate position of $131^{\circ}-33^{\circ} 5^{\prime}$ East Longitude and $5^{\circ}-6.5^{\circ}$ South Latitude.

\subsubsection{Geostrategic position}

Southeast Maluku is located in a strategic position, flanked by two large oceans which are fishing grounds (Fishing Ground), Banda Fishing Ground and Arafura Fishing Ground. The position of Southeast Maluku is politically and economically very advantageous. Because Southeast Maluku from the beginning has been a political and economic center in the southern part of Maluku. In addition, Southeast Maluku 
is also a very potential area in the trade sector because it is located on the trade route of southern eastern Indonesia to southern Papua [20].

\subsubsection{Area condition}

The geographical condition of Southeast Maluku Regency consists of coastal areas and small islands that have many straits and bays. As an archipelagic region, Southeast Maluku has great potential in the field of fisheries and tourism. In the field of fisheries, with a total coastal length of $632.15 \mathrm{~km}$, Southeast Maluku is rich in potential marine resources, both fish and non-fish. The problem that still occurs is the pattern of community behavior that is sometimes destructive in its use. the handling and rehabilitation of the marine and aquatic environment in accordance with the study of marine potentials is in a quite worrying condition. Apart from the opportunities, potentials and problems and challenges that exist, Southeast Maluku is also very vulnerable to economic, trade and transportation problems.

\subsubsection{Topography}

The topography between Kei Besar Island and Kei Kecil Island is relatively different:

a. The topography of Kei Kecil Island tends to be flat and sloping with an altitude ranging from 0 to $100 \mathrm{M}$ above sea level, there are several low hills in the middle and northern part of the island with a height of up to $115 \mathrm{M}$. The land slope of Kei Kecil Island ranges from 0-25 degrees with categories sloping;

b. The topography of Kei Besar Island is a hilly and mountainous area that stretches along the island with an average height of 500-00 M. The highest peak is Mount Dab, while the lowlands are only a narrow strip along the coast, with an average distance from the coast. 100 meters distance. The mainland slope of Kei Besar Island is divided and very steep with a slope of about 15-45 degrees and over 45 degrees at some points.

\subsubsection{Geology}

Based on the Geological Map of Indonesia (1965) the Southeast Maluku Islands are formed/composed of soil types including Podzolic, Rensina and Lithosol while rock types include Alluvium Steps, Coral Reefs, Seklis Habluk, Paleogene and Paleozoic Ulgans. Meanwhile, according to regional structure and typology, Southeast Maluku is divided into three types, namely the Coastal Plain, which is a narrow space along the coast, with an area of approximately 1 percent of the total land area; hills, generally in the southern and western parts of Kei Kecil Island, with 44 percent of the land area, as well as karst hills, which lie on Kei Besar Island and a small part of the northern part of Kei Kecil island with an area reaching 55 percent of the land area.

\subsubsection{Hydrology}

Southeast Maluku Regency has a main watershed (DAS) spread over both Kei Besar and Kei Kecil islands. Kei Besar Island with its characteristics, has quite a lot of springs. Specifically in the central and southern parts of the island of Kei Besar, as well as several points in the northern part.
a. Middle Great Kei:
1) River Wear Renfaal
2) Wetuar River
3) Erlarang River
b. Kei Southern Part of Weduar Sungai River

c. Northern Great Kei, Wear Hollay River and Ur. River While in the Kei Kecil Island area, there are at least 5 rivers with large enough water discharge, namely:

1) Nen Mas Il River;

2) Warwut River;

3) Sungai Use Semawi;

4) River Wear Hoarten; and

5) Jawav River.

The Southeast Maluku Regency also has one lake, namely Ablel Lake in Manyeuw District and several springs in Kei Besar District. In relation to the geological structure, Ecosystem Analysis of Water Supply for Living Services, shows: The results of the calculation of the Environmental Carrying Capacity and Carrying Capacity Index (DDDT-LH) of an area based on an ecoregion obtained a value of 0.24 which is a baseline when compared to the input base of an ecoregion and land cover obtained is 0.25 which is the average calculation result from Kei Besar Island and Kei Kecil Island.

\subsubsection{Climatology}

The climate in Southeast Maluku Regency is influenced by the Banda Sea, Arafura Sea, and the Indonesian Ocean and is overshadowed by Irian Island in the East and the Australian Continent in the South, so that changes occur from time to time. Seasonal conditions in Southeast Maluku Regency are as follows:

a. East season or dry season lasts from April-October.

b. West season or rainy season lasts from October February with the highest intensity in December and February.

c. The transition season takes place in March/April and October/November. Strong winds in January and February are followed by heavy rains and stormy seas. Wind conditions in Southeast Maluku Regency is as follows.

1) April-October, the East-Southeast Wind blows.

2) In April-September, 91 percent of the East, Southeast and South winds blow where the Southeast winds dominate 61 percent.

3) In October-March the Northwest Wind blows as much as 50 percent where the Northwest wind dominates by 28 percent.

Rainfall between 2,000-3,000 mm per year is found on Kei Kecil Island while on Kei Besar Island the rainfall is above 3,000 $\mathrm{mm}$ per year. In 2011 the total rainfall in Southeast Maluku Regency was 3,121 mm per year or an average of $260.1 \mathrm{~mm}$ per month, with 211 rainy days or an average of 17.58 rainy days per month.

\subsection{Marine tourism is a source of income for the Kei Indigenous people of Southeast Maluku Regency}

4.2.1 Marine tourism development can increase community income in Southeast Maluku District

Southeast Maluku Regency has natural potential that offers a lot of diversity of tourist attractions, both natural (nautical, beach, waterfall, forest) and cultural that can be developed into tourist destinations that need to be considered for visiting. Because of its enchanting natural beauty, Southeast Maluku Regency, better known as the Kei Islands, is often called "Fantastic Island". For tourists who like marine tourism activities and underwater rescue (diving), surfing, snorkeling, fishing (fishing) various types of fish, swimming (swimming), swimming (sun bathing), beach volleyball and playing kites on 
the beach [21].

Southeast Maluku Regency is an option to visit, because this area has many islands that have quite diverse marine potential with fine white sand. In addition to the maritime potential, Southeast Maluku Regency also has a stretch of pristine natural forest (virgiri), making it suitable for visitors who like tracking (exploring). Including the potential for waterfalls/baths available in this area.

In accordance with the Regional Medium-Term Development Plan (RPJMD) 2008-2013, it is stated about the development of the tourism sector, that tourism development is to develop the tourism potential of Southeast Maluku Regency with a focus on marine and cultural tourism through promotion and development of tourist objects and destinations. One of the tourism development priorities to be achieved in the next five years is the natural tourism of Pasir Panjang beach $( \pm 5 \mathrm{~km})$ including Ngur Bloat beach in Ngilngof Village and Ngur Sangadan Beach in Ohoililir Village and Ngidun in Ohoidertawun.

The development of marine tourism in this study is seen through tourism products as an important component in the industry. Marine tourism resources are classified as superior tourism, however, many potential natural resources have not been managed and utilized optimally and can increase community income and village income sources. The natural resources in the Third Tourism Village are in the form of coastal and marine natural potentials as well as various animals that have bright prospects for tourism to be managed and developed properly. The effectiveness of developing natural resource potential for tourism certainly requires local government responsiveness and intensive coordination with village governments in formulating and implementing tourism policies that are able to attract domestic and foreign tourists to make tourist visits, many attractions are taken seriously both for tourist attraction as well as for the culture and nature owned by the Village [22].

Accessibility. Accessibility is a means and infrastructure that causes tourist destinations to visit a tourist area. Accessibility is the ease of reaching a tourist destination (location or tourist attraction), the availability of transportation modes to the object and attraction or tourist area, the quality of the road to the object/area, the ease of opening a tourist attraction through the ease of reading the signs or directions to the location. tourist attraction. Accessibility is one of the important factors in the development of tourism. Good accessibility support will increase travel time to the destination Tourism Village. This is very influential on the interest of tourists as well as the assessment / perception of tourists towards the destination Tourism Village.

There are many and varied tourist objects in Southeast Maluku, apart from the dominant natural attractions, there are also cultural attractions. To achieve tourist destinations that are spread across each sub-district in Southeast Maluku, the quality of accessibility is one of the determining factors as an effort to attract tourists to tourist sites. The Tourism Village in Ohoi Ngilngof can be visited or can be visited using a rental car, private vehicle or motorcycle taxi with a travel time of 45 minutes, the Tourism Village in Ohoililir using a rental car, motorcycle taxi or private vehicle with a travel time of 45 minutes from Langgur City, while the Ohoi Cultural Village Ohoidertawun can be reached using a rental car, motorcycle taxi or private with a travel time of 50-60 minutes when the road conditions are narrow and damaged.
The problems experienced by Regency K56 with land transportation are in accordance with BPS data [23] in 2013 Regency roads connecting villages of a total length of 432.35 $\mathrm{Km}$, the total condition of damaged roads in Southeast Maluku is 323 , while those in good condition are only $108.79 \mathrm{Km}$. In addition Accessibility Problems related to Foreign Tourist Visits.

Countries and locals from outside the island of concern, namely Air and Sea Accessibility, are very concerned about expensive conditions and long travel times. Air transportation facilities that serve flights to and from Southeast Maluku Regency so far are Merpati's CASA type aircraft with the Ambon-Tual-Dobo PP flight route with a frequency of twice a week, while the Tual-Ambon round-trip flight route is served twice a day. by the type of aircraft ATR72 series 500 owned by Wings Air and ATR 42 owned by Trigana Air once a day, judging by the frequency with the trend of ferry development which continues to increase while the number of flights that results in limited ticket prices reaching 1 million so that it becomes one of the considerations for tourists to visit.

In contrast to Air Accessibility, Accessibility to reach Southeast Maluku Regency by Sea is relatively cheaper, but Sea Accessibility serves the shipping of the people. The ships managed by PT. PELNI, such as: KM. SLEEP.

Supporting Facilities. Tourism support facilities are an important component in the tourism industry. Tourism supporting facilities are one of the tourism products or what is known as aminities (read aminities) are everything that can be sold as tourism commodities. The main facilities or facilities at a tourist attraction are the main prerequisites for increasing tourist visits to a tourist attraction.

Related to that context, there are three types of facilities that are the basic needs of tourists visiting tourist attractions, namely places to stay (loading), eating and drinking (food and beverage), and services to tourist desires related to souvenirs or souvenirs (support industries).

The Maluku Regency Government has actually provided Cottages in Tourism Villages in Ohoi Ngilngof 5 units, in Ohoi Ohoililir as many as 3 and in Ohoi Ohoililir as many as 1, but the reality is that the problem of miscommunication between the local government as a provider of facilities and the Village Government as the manager so that the cottages in Ohoi Ngilngof did not work as expected, while the ones that operated well in Ohoi Ohoililir and Ohoi Ohoidertawun.

The second aspect besides service is standardization in menus and presentation of food and beverages. Services by introducing local specialties and drinks must pay attention to nutritional and health standards. Local food and drinks can be packaged and offered into something of an international standard. Apart from local food and drinks, local fruit can also be served. When is the way of presentation or method of preparation, serving and eating culture adapted to the local culture which has a high selling value. The serving of food and beverages can be in the form of restaurants and restaurants. There are 47 dining facilities in Kei Kecil District in total in urban areas, while those in the Tourism Village are only 2 pieces, one in Ohoililir and the other in Ohoi Ngilngof, this results in difficulties for tourists visiting the area. tourist village to enjoy the existing tourist charm while enjoying the typical food of the tourist village.

One of the important facilities is the telecommunications facility which is one of the needs that is widely used by tourists is the fulfillment of communication needs outside the tourist destination. Communication services in the main tourist 
destinations are telecommunications stalls. Generally bring cell phones to tourist attractions, therefore communication network services by cellular providers are very important.

In the field it is illustrated that the manager of the tourist attraction has not provided communication facilities to support the communication of tourists while in the tourist attraction area, such as telecommunications stalls as an alternative communication facility. In the development of communication technology, although the use of cellular phones is very dominant or very rarely used, the existence of wartels is still maintained for emergency use if tourists do not bring cell phones or bring cell phones but find a network (signal) or run out of battery.

The service quality of the Tourism Village is also seen from the restroom being very important in tourist areas in providing a sense of comfort for visitors and tourists, the toilet is the main requirement that must exist in tourist attractions, besides the existence of toilets illustrates great attention to the Health and Hygiene of the Village Environment Tour. There are 2 toilets each built in every tourist village that is abandoned and can no longer be used by visitors and tourists, the construction of toilets is carried out by the community to meet the needs of visitors for toilets but the situation is not as expected.

The availability of health facilities and infrastructure is also very necessary in supporting tourism activities, because tourists who travel can experience fatigue or even sometimes fall ill, this is due to changes in factors or unfavorable body conditions. The sick condition will be very disturbing and reduce the sense of enjoyment in doing tourism, so tourists must get certainty about the availability of health service facilities and infrastructure at tourist destinations. The health service facilities are: hospitals, health centers and pharmacies. Health facilities and medical personnel in tourist villages according to the results of observations have not provided maximum health insurance to tourists, where the condition of the health center is maintained and there is still a lack of health workers stored in the tourist village.

The existence of this gift shop is very necessary as a means of supporting tourism because tourists will usually buy goods that are characteristic of the area as souvenirs or souvenirs. The explanation above is in accordance with the results of observations, it is found that in the tourist village there are no shops selling souvenirs in the form of handicrafts that describe the tourist charm they have, so that tourists from outside the area cannot remember their journey in the tourist village, besides the expected handicrafts. can increase people's income is still far from what is expected.

\subsection{Factors that influence non-compliance with marine tourism managers UUPPLH-2009 in the Kei Customary Law community}

There are several factors that influence the occurrence of environmental damage in marine tourism sites in Maluk Tenggata Regency, especially the damage to coral reefs. Coral reefs are complex and unique ecosystems that are characterized by the diversity of their inhabitants' biota. The relationship between biotic and abiotic components is very close. Therefore, exploitation of one type of biota can lead to changes in the population of other biota. The main causes of damage to coral reef ecosystems are generally caused by natural and human factors.

A balance needs to be done because the superior coastal and marine resources in the coastal, marine and small islands of
Southeast Maluku Regency are mostly renewable natural resources (renewable resources) which are very vulnerable to damage due to uncontrolled activities. In addition, in order to overcome the problem of damage to the coral reef ecosystem and at the same time in the effort of sustainable management, it is necessary to make efforts to rehabilitate coral reefs in the Ohoi Ngurbloat area in Kei Kecil District. The aim of this research is to assess the damage to coral reef ecosystems in Ohoi Ngurbloat, Kei Kecil District, Southeast Maluku Regency [24].

Factors that affect coral reef ecosystems caused by:

a. anthropogenic (human activity)

b. non-anthropogenic (ecological changes, natural factors), including: fishing using fish bombs, arrow nets and traps. taking for building materials and decoration and wall decoration, and

c. Awareness of people living around marine tourism areas in Southeast Maluku Regency.

Public perception of the condition of coral reefs in the waters of Ngurbloat Beach is influenced by the level of education and poverty. The Strategic Plan for the management of coral reefs in the waters of Ngurbloat Beach is as follows: Determination of zoning of coral reef areas according to the carrying capacity of the environment; Determination of activities or businesses that may or may not be carried out in each designated zone; Fish control using environmentally friendly fishing gear and carried out at the right location and season. increasing awareness and compliance of fishing communities in Ngurbloat Beach on the importance of coral reefs as an effort to optimize the use of natural resource conservation.

The influencing factors as mentioned above are also in accordance with what Soerjono Soekanto has stated in the Theory of Legal Effectiveness, namely: a. Legal factors, b. Law Enforcement Factor, c. Factors of Legal Facilities or Facilities d. Community Factors and e. Human Cultural Factors.

\subsection{Factors that affect the level of community economic income with the existence of marine tourism in Southeast Maluku Regency}

Results Based on the research, it can be seen that the venture capital variable has a strong or significant effect on people's income on Marine Tourism to the Kei Indigenous people of Southeast Maluku Regency. These results are also in accordance with research conducted which show that there is a positive and significant effect of working capital on income. The greater the capital or production factors owned, the higher the income received.

Capital is money that is not spent, so it is saved and then invested. The important role of capital in increasing output is also explained in Adam Smith's theory, which says that capital is an element of production that will actively determine the level of output. The amount of output produced is largely determined by the amount of capital used [25]. Therefore, by increasing the amount of capital used, it will also increase income because the higher the capital used it will also determine the income earned because the business to be pioneered will be extensive with large capital. So it can be said that the greater the capital, the more it will be able to increase or increase productivity so that it can increase and also increase income. This is in accordance with research conducted which state that capital has a positive and 
significant effect on income. The study also states that one way to increase income is to increase capital [26].

Without sufficient capital, the business cannot carry out business activities optimally so that it will affect the level of community income that will be obtained. In terms of ownership of their own business capital, not a few business actors do not have enough capital to provide their merchandise, so many other businesses sell goods other than their own goods.

In addition to the factors above, there are also several influencing factors, namely:

a. The Effect of Business Length on Community Income on Maritime Tourism for the Kei Indigenous Peoples in Southeast Maluku Regency

Based on the results of the study, it can be seen that the variable length of business is not significant to the income of the community on Marine Tourism in Southeast Moluccas Regency. This can be seen from the results of the regression analysis of the values obtained. The length of the effort can lead to the experience of doing business. Where experience can influence a person's behavior. The duration of business opening can affect the level of income of business actors in the business field, which will affect their productivity, so that they can increase efficiency and reduce production costs, which are smaller than sales results.

b. The Effect of Education Level on Community Income on Maritime Tourism in the Kei Indigenous Peoples in Southeast Maluku Regency

Based on the results of the study, it can be seen that the level of education of a person in doing a business is not influenced by the income of the community on Maritime Tourism in Southeast Maluku Regency based on empirical data in the field in terms of the level of education of the business community in Maritime Tourism, very minimal respondents choose education at the junior secondary level. This is because they do not have the cost to continue their education to a higher level. In addition, this study shows that the community of business actors in Maritime Tourism does not look at the level of education to engage in work so that the community as business actors does not affect people's income because it does not require professional age in the level of education but strength in work and ability to work. The results of the study are in line with Teguh Susilo.

c. The Influence of the Number of Visitors on People's Income on Maritime Tourism in Southeast Maluk Regency

Based on the research, it can be seen that the variable number of visitors has a significant effect on people's income in the Maritime Tourism of the Adar Kei Community in the Regency of Maluku Tenggara. According to who researched "Analysis of Factors Affecting the Number of Visitors to Coastal Ecotourism Objects in Southeast Moluccas Regency which aims to analyze the factors that influence the number of visits to Marine Tourism Objects. The dependent variable in this study is the number of visits. The results show that the number of visitors has a significant effect on income.

\section{CONCLUSION}

As a conclusion in this study, namely:

a. Factors that affect environmental damage (coral reef ecosystems in the Kei Indigenous people caused by: 1) anthropogenic (human activities), 2) nonanthropogenic (ecological changes, natural factors), including: fishing using fish, arrows nets and traps. Taking for building materials and wall decorations, dams 3) Awareness of people living around marine tourism areas in Southeast Maluku Regency.

b. The factors that affect the level of community income in marine tourism locations are influenced by business capital variables that have a strong or significant effect on people's income in Marine Tourism in the Kei Indigenous people of Southeast Maluku Regency. In addition to the factors above, there are also several influencing factors, namely: 1) The Effect of Business Length on People's Income on Marine Tourism 2) The Effect of Education Level, 3 The Effect of the Number of Visitors.

\section{REFERENCES}

[1] Marine Tourism Survey. (1979). Director General of Tourism,

http://jurnal.usahid.ac.id/index.php/pariwisata/article/vi ew/15/0, accessed on July 17, 2021.

[2] Kei Islands History. http://id.wikipedia.org/wiki/Kepulauan Kai, accessed on July 13, 2021.

[3] Law Number 32 of 2009 Concerning Environmental Protection and Management (UUPPLH-2009). https://referensi.elsam.or.id/2015/04/uu-nomor-32tahun-2009-tentang-perlindungan-dan-pengelolaanlingkungan-hidup-

2/\#: :text=Perlindungan $\% 20$ dan $\% 20$ Pengelolaan $\% 20 \mathrm{Li}$ ngkungan \%20Hidup \%20(PPLH)\%20menurut\%20UU\% 20no $\% 2032$,meliputi $\% 20$ perencanaan $\% 2 \mathrm{C} \% 20$ pemanfa atan $\% 2 \mathrm{C} \% 20$ pengendalian $\% 2 \mathrm{C}$.

[4] Angga, L.O., Latupono, B., Labetubun M.A.H., Fataruba, S. (2020). Application of hawear customary law in the prevention of pollution and environmental damage on the sea coast in southeast Maluku regency. International Journal of Sustainable Development and Planning, 15(5): 767-774. https://doi.org/10.18280/ijsdp.150519

[5] Helmi. (2012). Environmental Licensing Law. Jakarta Sinar Grafika. https://books.google.co.id/books/about/Hukum_perizina n_lingkungan_hidup.html?id=_vA6MwEACAAJ\&redir _esc=y.

[6] Kansil, C.S.T., Chiristine, S.T., Kansil. (1977). Constitutional Law of the Republic of Indonesia. Jakarta: Rineka Cipta. https://libraaceh.perpusnas.go.id/detailopac?id=26615.

[7] Bagir Manan, Increasing the Function of Community Control Against Legislative, Executive, Judiciary, Papers.

https://ejournal.unisba.ac.id/index.php/mimbar/article/vi ew/15https://ejournal.unisba.ac.id/index.php/mimbar/art icle/view/15, accessed on July 17, 2021.

[8] Angga, L.O. (2004). Akibat hukum tidak adanya pengaturan pengawasan dan evaluasi penataan ruang dalam perda rtrw provinsi malukU. Journal of Legal Studies.

https://www.academia.edu/39708158/akibat_hukum_tid ak_adanya_pengaturan_pengawasan_dan_evaluasi_pen ataan_ruang_dalam_perda_rtrw_provinsi_maluku.

[9] Angga, L.O., Saptenno, M.J. (2020). The formulation of green open spacein the regional regulation of spatial 
planning of Maluku Province. International Journal of Scientific \& Technology Research, 9(1). http://www.ijstr.org/paper-references.php?ref=IJSTR1019-23542.

[10] Angga, L.O., Latupono, B., Hamid Labetubun, M.A., Fataruba, S. (2020). Implementation of precautionaryprinciple in gold mine exploitation in Romang Island, Southwest Maluku regency by PT. Gemala borneo utama based on law number 32 year 2009. International Journal of Scientific \& Technology Research, 9(1). http://www.ijstr.org/paperreferences.php?ref=IJSTR-1019-24111

[11] Mustamin, D.M. (1972). Overview of the Development of Modern Types of State, Speech IV Law and Public Deception. Ujung Pandang: Penerbit Universitas Hasanudin.

[12] Friedman, W. (1971). The Stale ang the Rule of Law in a Mixed Economy. London: Steven \& Son.

[13] Hans, K. (1961) General Theory of Law and State. New Yor: Russel and Russel.

[14] 1945 Constitution of the Republic of Indonesia (UUD NRI 1945). https://www.blog.aksara.org/2011/06/the1945-constitution.html, accessed on July 17, 2021.

[15] Wisnuwardani, D.A. (2010). Legal Protection of State Assets Land Under the Control of the Ministry of Defense of the Republic of Indonesia, Summary of Legal Studies Doctoral Dissertation Program. Malang: Universitas Barawijaya Fakultas Hukum.

[16] Indonesia Dictionary. (2002). Jakarta: Balai Pustaka.

[17] Soekanto, S. (2007). Fundamentals of Sociology of Law.
Jakarta: PT Raja Grafindo Persada.

[18] Maria, S.W. (2001). Sumardjono, Guidelines for Making Research Proposals a Basic Guide, Penerbit Gramedia Pustaka Utama. Jakarta.

[19] Central Maluku District Government. https://malukutenggarakab.go.id/web/profil/letak-dankondisi-geografis.html, accessed on July 17, 2021.

[20] Laimeheriwa, S.H.A. (2020). Development of tourism villages in increasing community income in southeast Maluku regency (Study in Kei-Kecil District, Southeast Maluku https://doi.org/10.13140/RG.2.2.20289.99683

[21] Researcher Field Observation Results in 2013.

[22] Data from the Central Bureau of Statistics of Malra Regency in 2013.

[23] Netty, D.U., Sigit, H., Suwarno Hadisusanto, S. (2015). Study of environmental damage due to human activities in coral reef ecosystem case study: Ngurbiot Ohoi Beach, Kei Kecil District, Southeast Maluku Regency, Maluku Islands Province. 2015 Master's Degree in Environmental Science.

[24] Soerkartawi. (2002). Factors of Production in Goods and Services. Jakarta: PT. Bumi Aksara.

[25] Setiaji, K. (2018). Effect of capital, length of business and location on post-relocation market income. Journal of Economics and Business Education, Faculty of Economics, Unversitas Negeri Semarang, Indonesia.

[26] Saleng, A. (2004). Mining Law. Yogyakarta: UII Press, Anggota IKAPI. 